\title{
sciendo
}

\author{
WITOLD WOJDAN ${ }^{1}$, KRYSTIAN WDOWIAK ${ }^{1}$, ALEKSANDRA WITAS ${ }^{1}$, \\ JUSTYNA DROGOŃ ${ }^{1}$, WOJCIECH BRAKOWIECKI²
}

\section{The impact of social media on the lifestyle of young people}

\begin{abstract}
Introduction. Young people are particularly vulnerable to new trends in internet use. Schoolchildren often lose themselves in the virtual world, forgetting about the real world. This leads to difficulties in contact with family or peers, a decline in academic performance, and even to road accidents. Some young people try to gain popularity on the Internet at all costs, thinking that only this will make them better people. In some youth circles, people who are less popular in the Internet are excluded - social media are therefore another reason for dividing young people.

Aim. The aim of the study is to determine the habits related to the use of social media by young people in order to analyze the obtained data in terms of: assessing an addiction of the studied group, impact on private life, education and selecting the necessary educational programs.

Material and method. The study used an anonymous questionnaire conducted in electronic form on a group of students attending high schools and technical schools all over Poland. The study was conducted using a proprietary questionnaire (Google form) completed online. The questionnaire mainly consisted of closed-ended questions verifying habits related to using social media and a certificate (age, gender, voivodship, size of the place of residence, type of school). The following computer programs were used for statistical analysis of data: Statistica and Microsoft Excel.

Results. The research proved that the most popular social media among young people are Facebook, YouTube, Instagram and Snapchat. Most of the respondents spend 3-4 hours a day on social media. Most of the respondents neglect sleep and household chores because of them.

Conclusions. Young people spend too much time during the day using social media. Social media have a negative impact on school education and the length of sleep of young people. A large proportion of young people is unaware of the dangers that await them online, and that social media have a negative impact on interpersonal contacts in the real world, therefore it is necessary to increase the knowledge of young people about the dangers lurking on the Internet and introduce educational programs to solve this problem.
\end{abstract}

Keywords: youth, social media, internet, behavioral addictions, public health, habits.

DOI: $10.2478 /$ pjph-2020-0003

\section{INTRODUCTION}

The beginning of the $21^{\text {st }}$ century is so-called the era of new addictions. Researchers of the subject more and more often describe not only addictions to psychoactive substances (alcohol, nicotine, drugs, drugs and legal highs), but also other, which we call behavioral addictions or activity addictions. These include: playing computer games, "being online" (socalled network addiction), workaholism, shopaholism, sex addiction, obsessive overeating, participation in gambling leading to pathological gambling. These are addictive behaviors that a person is not able to control, despite the fact that they disturb many areas of his functioning [1]. Young people are particularly vulnerable to new trends in internet use. It is a tool that brings with it many good solutions, such as the possibility of maintaining contact between people living far apart, or easy access to information, as well as bad ones - including the threat of sexual abuse and discrimination. Schoolchildren often lose themselves in the virtual world, forgetting about the real world. This leads to difficulties in contact with family or peers, a decline in academic performance, and even to road accidents. Social media introduced into the life of young people the need for publicity, to be noticed. Some young people are particularly susceptible to this trend, and they try to gain popularity at all costs, because they believe that only popularity will make them better people on the Internet. In some youth circles, people who are less popular in the Internet are excluded by creating a group of only "popular" people - social media are therefore another reason for dividing young people. Young people who become popular easily have a tendency to be constantly in social media - the desire to maintain their position leads to addiction. For some people, the loss of popularity can lead to serious health consequences, including depression. When discussing the dangers of social media, the possibility of extorting confidential data from a young person is also worth mentioning.

\footnotetext{
${ }^{1}$ Studenckie Koło naukowe przy Katedrze i Zakładzie Zdrowia Publicznego - Uniwersytet Medyczny w Lublinie, Poland

${ }^{2}$ Chair and Department of Public Health, Medical University of Lublin, Poland
} 


\section{AIM}

Determining the habits of using social media in young people in order to analyze the obtained data in terms of: the impact of this activity on interpersonal contacts, the assessment of the addiction of the group and the selection of necessary educational programs.

\section{MATERIAL AND METHOD}

An anonymous questionnaire survey was conducted in an electronic form on a group of 330 students (288 women and 42 men) aged from 15 to 21 , attending high schools (316 people) and technical schools (14 people) all over Poland. Information on the age of the respondents is presented in Table 1, the distribution of the provinces in which the respondents live is presented in Table 2, while the size of the place of residence of the respondents is presented in Figure 1.

TABLE 1. Age of respondents.

\begin{tabular}{lc}
\hline \hline Median & 18 \\
\hline Fashion & 18 \\
\hline Fashion multiplicity & 120 \\
\hline Lower quartile & 18 \\
\hline Top quartile & 19 \\
\hline
\end{tabular}

TABLE 2. Distribution of the provinces in which the respondents live.

\begin{tabular}{lcc}
\hline \multicolumn{1}{c}{ Province } & Number & Percent \\
\hline Lower Silesia & 23 & $7 \%$ \\
\hline Kuyavian-Pomeranian & 14 & $4 \%$ \\
\hline Lublin & 22 & $7 \%$ \\
\hline Lubusz & 8 & $2 \%$ \\
\hline Lódź & 23 & $7 \%$ \\
\hline Lesser Poland & 22 & $7 \%$ \\
\hline Masovia & 35 & $11 \%$ \\
\hline Opole & 3 & $1 \%$ \\
\hline Subcarpathian & 30 & $9 \%$ \\
\hline Podlaskie & 10 & $3 \%$ \\
\hline Pomerania & 15 & $5 \%$ \\
\hline Silesian & 29 & $9 \%$ \\
\hline Świętokrzyskie & 45 & $14 \%$ \\
\hline Warmian-Masurian & 11 & $3 \%$ \\
\hline Greater Poland & 32 & $10 \%$ \\
\hline West Pomerania & 8 & $2 \%$ \\
\hline & & \\
\hline
\end{tabular}

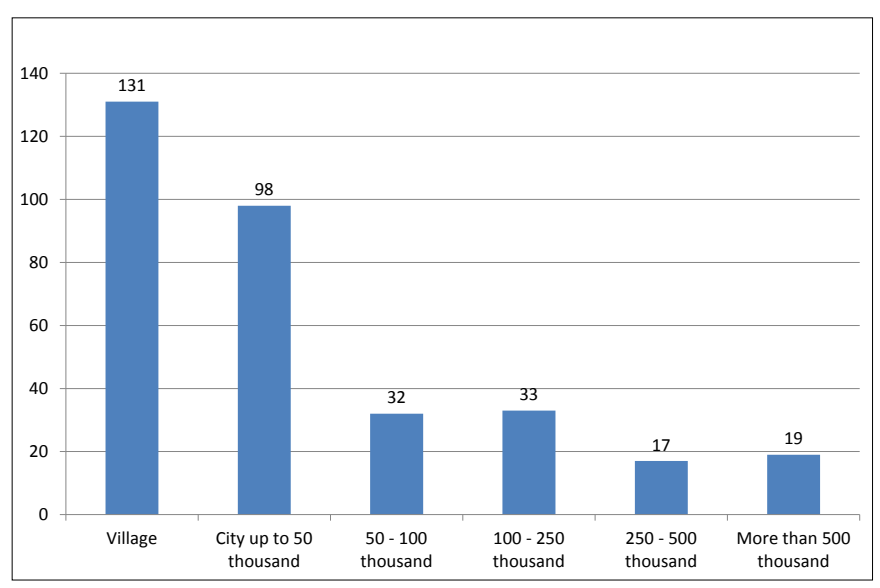

FIGURE 1. Size of the respondents' place of residence.
The study was conducted using a proprietary questionnaire (Google form) completed via the Internet. The questionnaire consisted mainly of closed questions, verifying habits related to using social media, and a record (age, gender, voivodship, size of the place of residence, type of school). The following computer programs were used for statistical analysis of the data: Microsoft Excel (graphs) and Statistica (statistical analyzes). The following were used for statistical analyzes: Pearson's Chi square test (if $\mathrm{p}<0.05$ it was considered that there is a relationship between the data), V. Cramer's test (to determine the strength of the dependency) and the contingency coefficient (when the V. Cramer test was unavailable).

\section{RESULTS}

The highest percentage of secondary school students surveyed use portals consisting in sharing photos (Instagram, Snapchat). Also, a large number of respondents use portals enabling contact with friends and sharing opinions on various topics, the most popular among them is Facebook, which is $84 \%$ more popular than Twitter. A similar dependence occurs in the case of websites that allow you to watch Internet videos that are very popular, however, a much larger part of the respondents uses YouTube. Services gathering users with similar interests (Pinterest and Tumblr) are visited by about half of the respondents. The least popular among high school students are social networks whose target group are adults - (LinkedIn, Tinder).

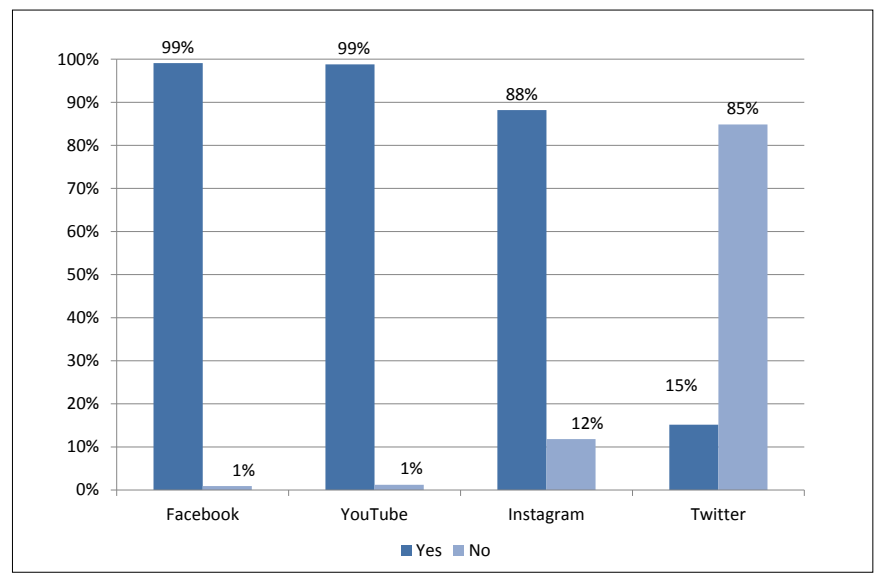

FIGURE 2. Social media used by the respondents (1).

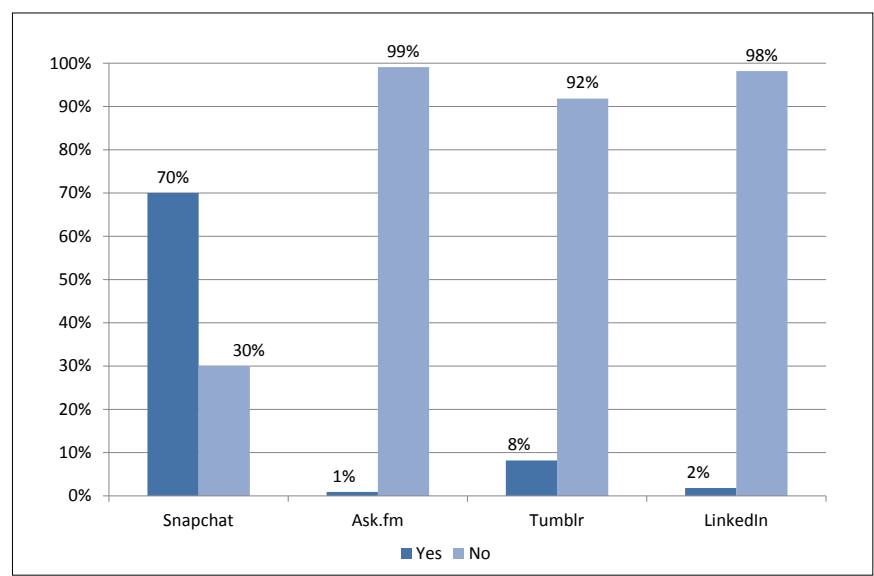

FIGURE 3. Social media used by the respondents (2). 


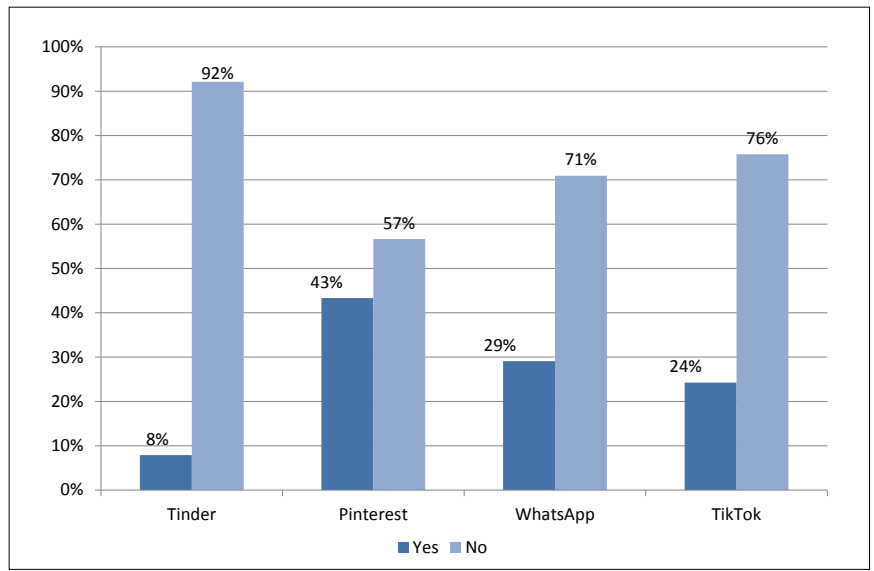

FIGURE 4. Social media used by the respondents (3).

school students surveyed use portals consisting in sharing photos (Instagram, Snapchat). Also, a large number of respondents use portals enabling contact with friends and sharing opinions on various topics, the most popular among them is Facebook, which is $84 \%$ more popular than Twitter. A similar dependence occurs in the case of websites that allow you to watch Internet videos that are very popular - however, a much larger part of the respondents use YouTube. Services gathering users with similar interests (Pinterest and Tumblr) are visited by about half of the respondents. The least popular among high school students are social networks whose target group are adults - (LinkedIn, Tinder).

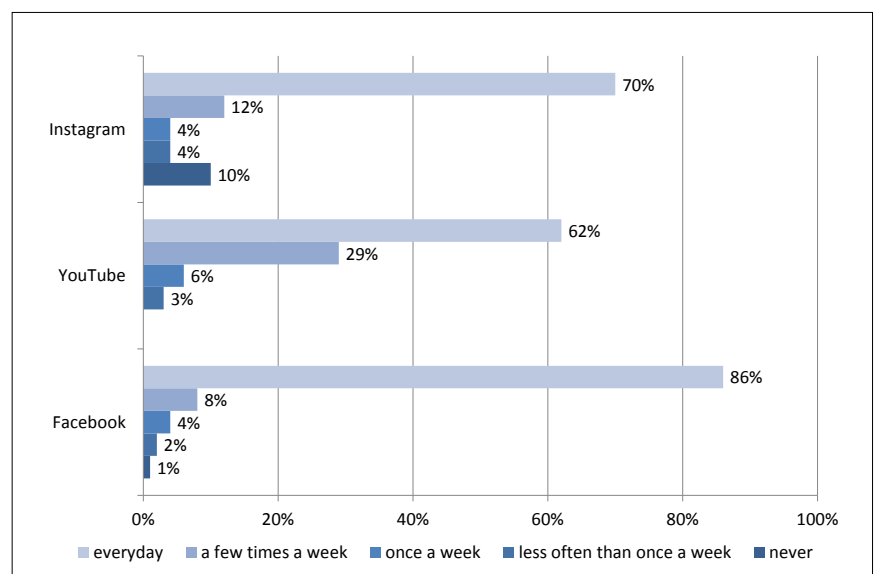

FIGURE 5. The frequency of using the Instagram, YouTube and Facebook platforms among the respondents.

Young people most often use Facebook $-86 \%$ of respondents $\log$ in to their account on this portal every day, and $8 \%$ several times a week. The results show that almost all respondents use YouTube. Most of the students (62\%) visit this website every day, $29 \%$ several times a week. Instagram is also frequently visited by young people $-70 \%$ of respondents do it every day. When it comes to $12 \%$ of respondents, they use this application several times a week (Fig. 5).

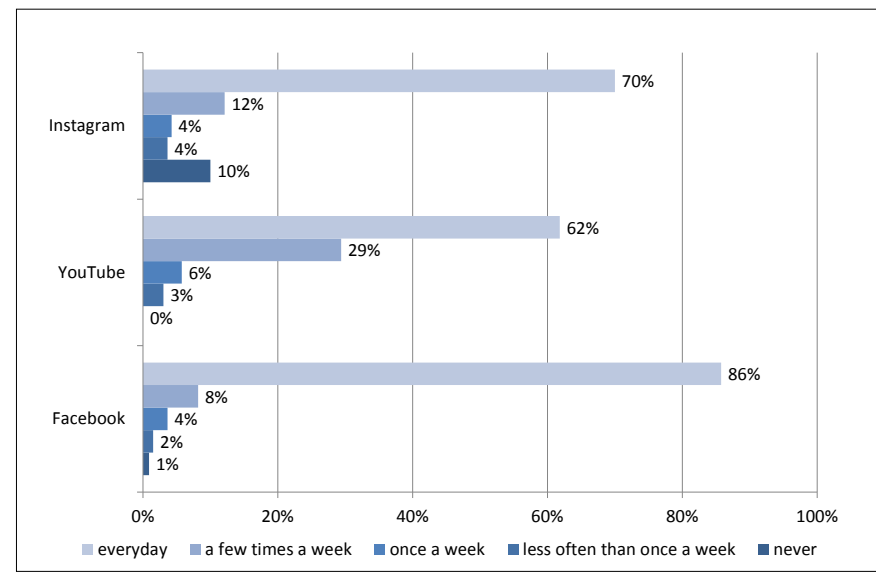

FIGURE 6. The frequency of using the Ask.fm, Snapchat and Twitter platforms among the respondents.

Ask.fm currently is not a popular website among young people $-99 \%$ of respondents do not use it at all. More than half of the students $(52 \%)$ check Snapchat notifications every day. A definite minority rarely visit this platform $(5 \%)$ or do not use it at all (28\%). As many as $83 \%$ of respondents do not admit to using Twitter (Fig. 6).

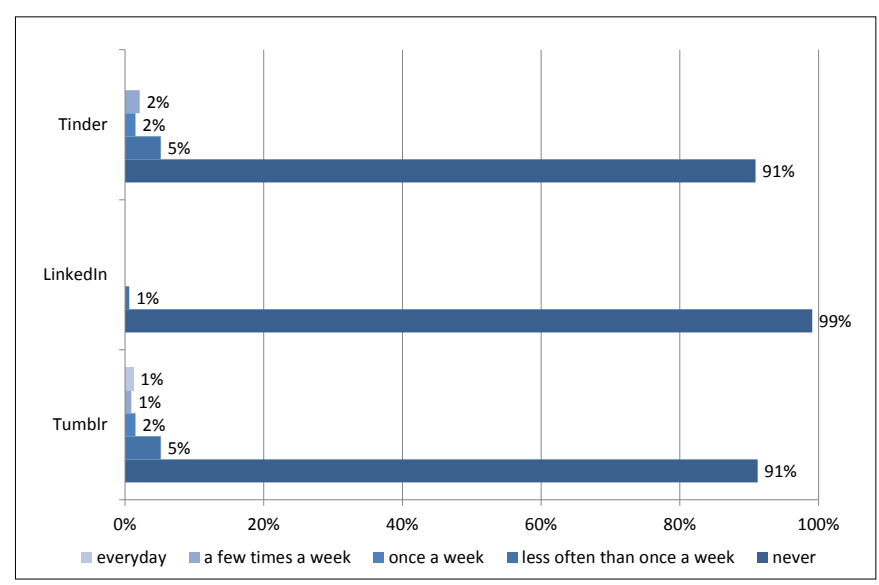

FIGURE 7. The frequency of using the Tinder, LinkedIn and Tumblr platforms among the respondents.

Dating apps are not often used by high school students: $91 \%$ of respondents do not use Tinder, and only $5 \%$ use it less than once a week. LinkedIn is not also very popular - $99 \%$ of respondents do not use it. The Tumblr microblogging platform is also not used often by high school students $-91 \%$ of respondents do not use it (Fig. 7).

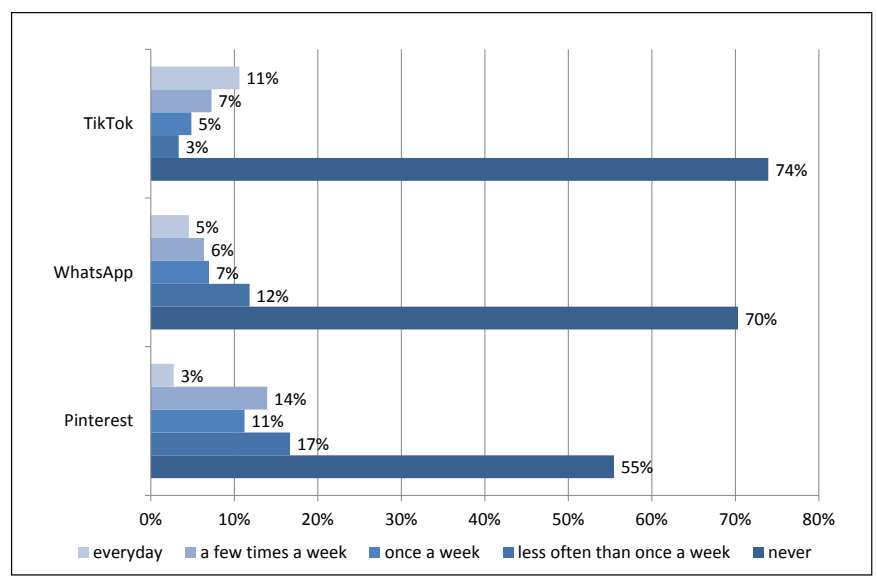

FIGURE 8. The frequency of using the TikTok, WhatsApp and Pinterest platforms among the respondents. 
Every tenth respondent uses the TikTok application every day. The vast majority of respondents do not use this portal at all $(74 \%)$. More than $2 / 3$ of the respondents do not use WhatsApp messenger at all. A small percentage of respondents (3\%) logs into the Pinterest social network every day. When it comes to $17 \%$ of students, they visit Pinterest less than once a week, and 55\% do not do it at all (Figure 8).

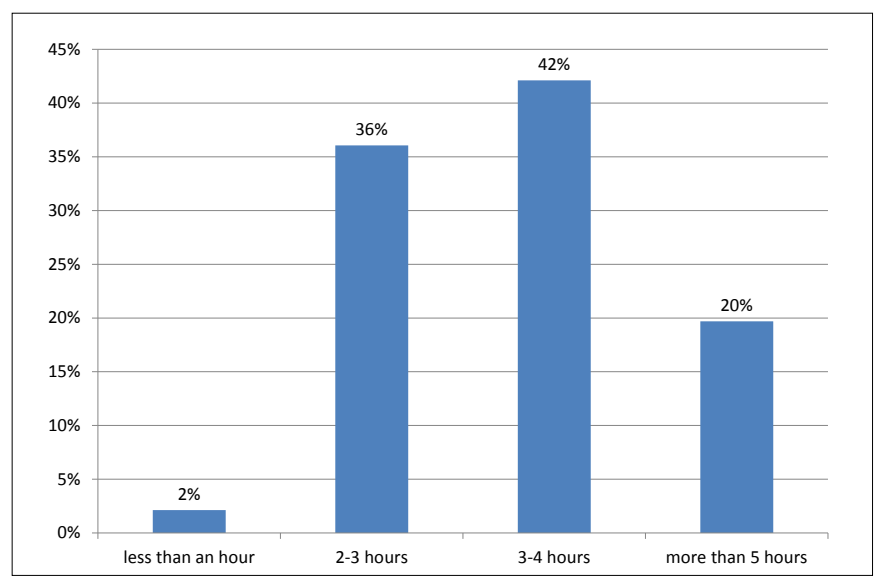

FIGURE 9. Amount of daily time devoted to social media among respondents.

Only $2 \%$ of respondents use social media for less than an hour a day. The vast majority of respondents spend much more time on social networking sites $-36 \%$ of respondents use them 2-3 hours, $42 \%-3-4$ hours, and every fifth respondent admits that he/she spends more than 5 hours a day on the Internet (Figure 9).

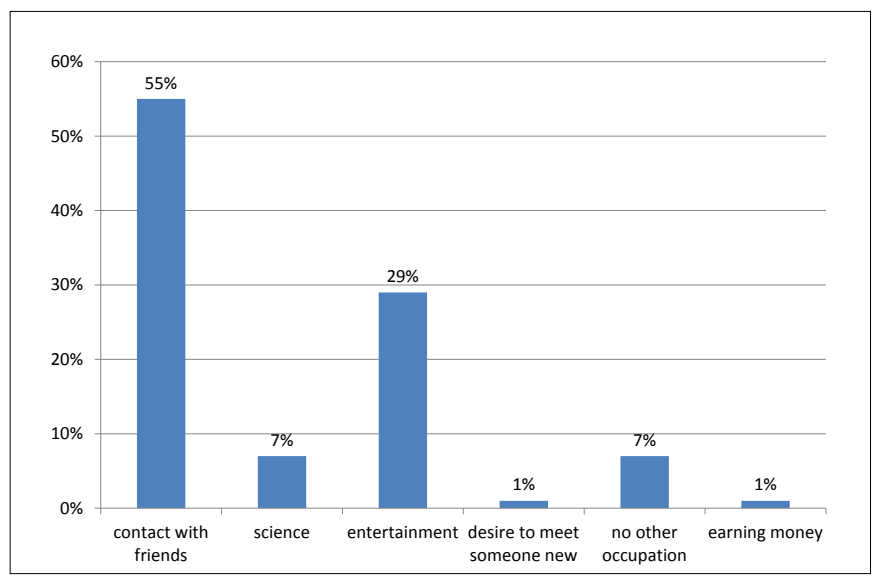

FIGURE 10. The main reason why the respondents use social media.

The main reason for using social media indicated by the surveyed youth (55\%) is the desire to keep in touch with friends, which is possible thanks to Facebook, Instagram, Snapchat or WhatsApp. Entertainment is also an important aspect of social media for the respondents, as $29 \%$ of people indicated this answer. Entertainment can be understood as the use of websites such as Youtube, Instagram or TikTok. A small number of respondents (7\%) use social networking sites for learning, which is made possible by the authors of, for example, high school graduation guides published on Facebook or YouTube [2,3]. The same number of respondents (7\%) admit that they use social networking sites because they have no other, more interesting job. Every hundredth respondent indicated that he uses social media to meet someone new, which is possible thanks to applications such as Tinder, Badoo or eDarling. The minimum number of surveyed youth (1\%) uses social media for profit, e.g. promoting brands on Instagram (Fig. 10).

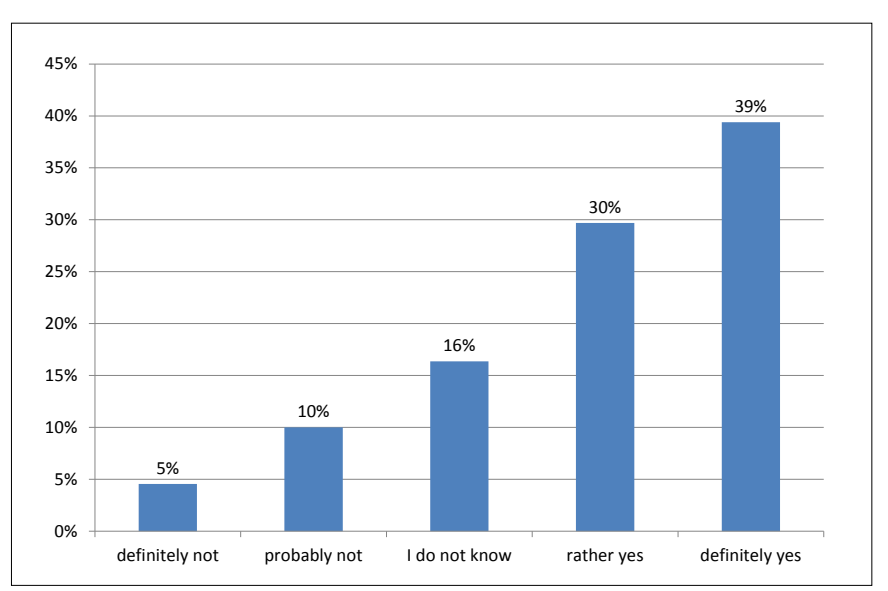

FIGURE 11. Possibility of not using social media by respondents for one day.

Most of the teenagers surveyed (39\%) admitted that they could easily go through the whole day without using social media. One in twentieth respondents would definitely not be able to cope with such a challenge, and one in ten claims that he/she would rather not be able to cope (Fig. 11).

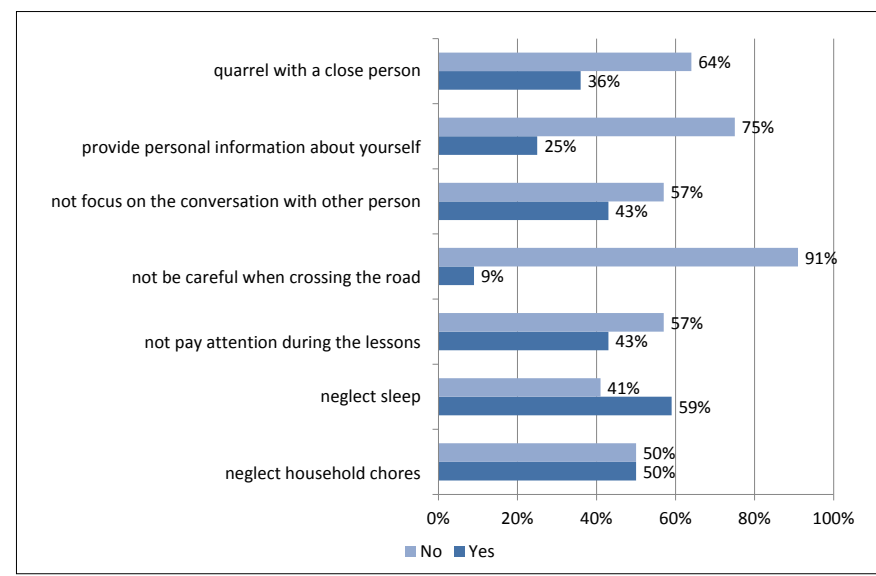

FIGURE 12. "Do you ever ... due to social media?

Among the surveyed high school students, the largest number neglect sleep due to the use of social media (59\%). Every second respondent admitted to neglecting household duties as a result of excessive use of social networking sites (50\%), while almost half of the respondents, due to using social media, have a problem with maintaining concentration during a conversation with another person (43\%) and during lessons $(43 \%)$. Some of the respondents had an argument with a loved one as a result of using social media (36\%), and every fourth respondent admitted that he/she had shared personal information about themselves on social networks. The smallest number of respondents happened not to be careful when crossing the road as a result of using social media (9\%) (Fig. 12).

Most respondents (40\%) admit that they check social media every several minutes, a similar number of respondents $(36 \%)$ do it every hour/two. Almost every tenth respondent checks social media continuously (Fig. 13). 


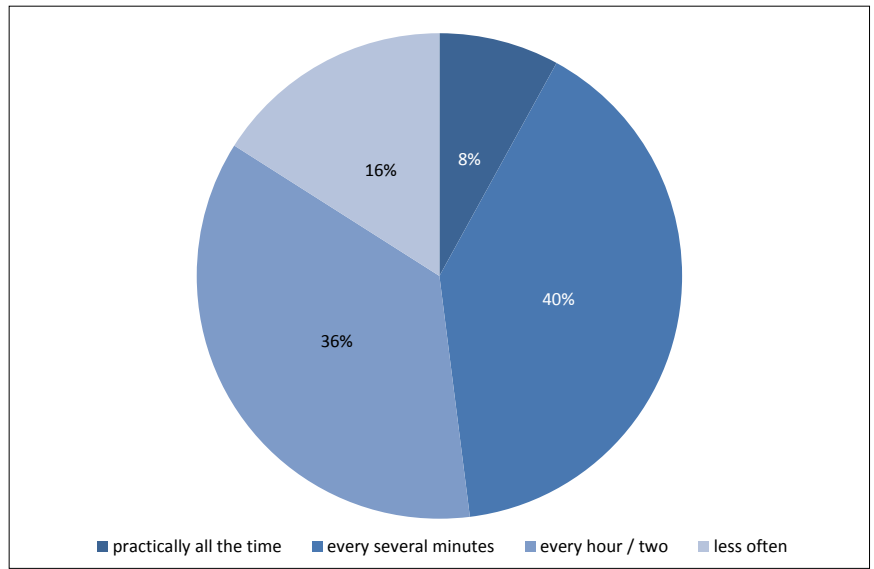

FIGURE 13. The frequency with which the respondents check if there was something new in social media.

\section{DISCUSSION}

\section{"What social media do you use?"}

Compared to the 2016 research, the percentage of high school students using Facebook and LinkedIn has not changed. There was a significant difference in the number of Instagram users which increased by $63 \%$, as did the number of Snapchat users which increased by $50 \%$. In the case of both of these social networking sites, there was an increase in the number of young people using these websites, but in 2017 both of these websites significantly increased in popularity in Poland. There is also a slight increase in YouTube users, from $86 \%$ to $99 \%$. The popularity of Ask.fm changed negatively, which decreased from $20 \%$ to $1 \%$ compared to the 2016 research. The increase in the number of users is also noticeable in the case of the Twitter, which changed by $5 \%$ compared to 2016 , which is probably due to the influx of middle school students to upper secondary schools, among which, according to the same research from 2016, the number of users was 20\% [4] (Fig. $2,3,4)$. Almost every tenth high school student who took part in the presented study has an account on the Tinder dating portal (Fig. 4). Nowadays, a large number of young people look for sympathy on the Internet, while few of them are interested in using applications prepared for this purpose [5,6]. According to research carried out in 2019 at the request of NASK's academy, the WhatsApp application was listed among the most frequently used by $11.9 \%$ of students of upper secondary schools [7] (Fig. 4).

Pearson's Chi square test showed a relationship between gender and the use of Instagram $(p=0.002)$, Pinterest, and TikTok $(p=0.046)$. The contingency coefficient showed that this relationship is rather weak when using Pinterest, in other cases it is weak.

Pearson's Chi square test showed a relationship between the size of the place of residence and the use of TikTok. V. Cramer's test showed that this dependence is weak.

\section{"How often do you use the given social media?"}

The number of $5 \%$ of respondents admit to using WhatsApp, while $6 \%$ of respondents does it several times a week, which can be concluded that the popularity of this application remains at a similar level (Fig. 4). In a survey conducted by CBOS in 2018 a very small percentage of young people in high school age mentioned having an account on the TikTok platform, which, when confronted with the results of the own research, leads to the conclusion that more and more students show interest in this application (Fig. 4) [5]. A similar situation took place in connection with the Pinterest portal, to which almost half of the respondents in the own study logged in (Fig. 8). The EU NET ADB research made it possible to show that social networks are one of the most frequently undertaken forms of Internet activity by young people living in Europe. The social networking site is visited daily by $65.8 \%$ of EU NET ADB respondents [8]. These studies did not distinguish individual portals - comparing these data with the results obtained during the own study, it can be concluded that the number of users using social networking sites every day has increased significantly. Only the Facebook platform itself is logged in by $86 \%$ of respondents every day, and the percentage of users using Instagram with the same frequency also exceeded the results obtained during the above-mentioned study (Fig. 5).

Pearson's Chi square test showed a relationship between gender and the frequency of using Instagram $(\mathrm{p}=0.017)$, Twitter $(p=0.026)$, LinkedIn $(p=0.00094)$, and Pinterest $(p=0.00008)$. V. Cramer's test showed that this dependence is rather weak when using LinkedIn and Pinterest, in other cases it is weak. Pearson's Chi square test showed no correlation between the size of the place of residence and the answer to this question.

\section{"How much time do you spend on social media a day?"}

The study shows that as many as $20 \%$ of respondents spend more than 5 hours a day on social media, which is an alarmingly high number, considering that young people attend school during the week, where they spend most of the day. Therefore, some young people spend practically all their free time on social media (Fig. 9) [4]. Pearson's Chi square test showed no correlation between gender and size of the place of residence and the answer to this question.

\section{"What's the main reason why you use social media?"}

The study shows that young people use social media mainly for contact with friends and for entertainment purposes. Much fewer respondents use social media for educational purposes (Fig. 10). Social media offers great educational opportunities and young people should pay attention to this application. Pearson's Chi square test showed a relationship between gender and the answer to this question. The V. Cramer's test showed that this relationship is rather weak.

Pearson's Chi square test showed no correlation between the size of the place of residence and the answer to this question.

\section{"Would you be able not to use any social media around the clock?"}

The survey shows that most adolescents believe they would be able not to use social media overnight. The scary thing is that almost $1 / 6$ of the youth would not be able to survive a day without social media (Fig. 11). This is especially dangerous as it may indicate an existing fear of exclusion that often leads to a potential addiction to social media. Considering the fact that young people often do not pay attention to the discussed problem, it is necessary to familiarize young people with the consequences of Internet addiction [9].

Pearson's Chi square test showed no correlation between gender and size of the place of residence and the answer to this question. 


\section{"Do you ever ... due to social media?"}

Due to the use of social media, 59\% of the surveyed high school students sleep less (Fig. 12), this is a disturbing statistic considering that, according to the research, teenagers who use social networking sites excessively before falling asleep are at risk of sleep disorders [10]. On the other hand, $43 \%$ of respondents admitted not paying attention to lessons due to the use of social media (Figure 12), and considering the fact that, according to research from $2014,78 \%$ of respondents agreed that the use of social media negatively affects the learning of young people [11], it may indicate a negative impact on the development of the young person. In addition, according to research from 2018, 14\% of respondents consider causing distraction to be the most negative effect of using social media [12], and our research shows that almost half of the respondents have lost their focus as a result of using social networking sites (Fig. 12). Among the respondents, 36\% admitted that they had a conflict with a loved one as a result of using social media (Fig. 12), and the negative impact on interpersonal relationships is, according to $17 \%$ of respondents from the research conducted in 2018, as the most negative result using social media [12]. According to research, every fourth respondent shared personal information about himself on social networking sites (Fig. 12), however, according to research conducted on Silesian youth in 2016, $41 \%$ shared their photo on the Facebook [13], which may indicate that a large proportion of high school students do not consider sharing photos private information about themselves. Pearson's Chi square test showed a relationship between gender and the answer "neglect sleep" ( $p=0.0086)$. V. Cramer's test showed that this dependence is weak. Pearson's Chi square test showed no correlation between the size of the place of residence and the answer to this question.

\section{"How often do you check, for example on your phone, if there is something new in social media?"}

Worrying is the fact that every tenth surveyed teenager uses social media practically all the time, many young people admit that Facebook stays on 24/7, and the teenager feels a constant need to check up-to-date information that appears every now and then (Fig. 13).

Pearson's Chi square test showed no correlation between gender and size of the place of residence and the answer to this question.

\section{CONCLUSIONS}

1. The most popular social media among young people are: Facebook, YouTube, Instagram and Snapchat.

2. Dating sites are not popular among teenagers.

3. Young people spend too much time during the day using social media.

4. Few of the young people use social media for research purposes.

5. Most of the youth believe they can break away from social media daily.

6. Social media has a negative impact on school education and adolescent sleep length.

7. A large proportion of young people are unaware of the dangers they face online. Educational programs should be introduced to address this problem.
8. A small proportion of young people admit that they cannot tear themselves away from social media.

9. Social media has a negative impact on people-to-people contacts in the real world.

\section{REFERENCES}

1. Warzecha K. Statystyczna analiza aktywności internetowej śląskiej młodzieży w kontekście uzależnienia od Internetu. Stud Ekon. Zesz Nauk Uniwersytetu Ekonomicznego w Katowicach. 2016;264:75-96.

2. Borkowska A, Witkowska M. Media społecznościowe w szkole. Warszawa: NASK - Państwowy Instytut Badawczy; 2017.

3. Wąsiński A, Tomczyk Ł. Aktywność młodzieży oraz rola rodziców w przestrzeni mediów sieciowych w perspektywie zagrożeń neto holizmem na przykładzie badań własnych. Rola informatyki w naukach ekonomicznych i społecznych. Innowacje i implikacje interdyscyplinarne. Kielce: Wyższa Szkoła Handlowa; 2011. p.178-95.

4. Tanaś M. Nastolatki wobec Internetu. Warszawa: Naukowa i Akademicka Sieć Komputerowa; 2016.

5. Grabowska M, Gwiazda M. Młodzież 2018. Wydanie I. Warszawa: Centrum Badania Opinii Społecznej i Krajowe Biuro ds. Przeciwdziałania Narkomanii, 2019.

6. Wąż K. Wybrane składowe obyczajowości seksualnej młodzieży. Poznawanie partnera. Rocz Lub. 2018;44(1):305-23.

7. Kamieniecki W, Bochenek M, Tanaś M, et al. Raport z badania Nastolatki 3.0. III wydanie. Warszawa: NASK - Instytut Badawczy; 2019.

8. Makaruk K. Korzystanie z portali społecznościowych przez młodzież. Wyniki badania EU NET ADB. Dziecko krzywdzone. Teoria, badania, praktyka. 2013;12(1):69-79.

9. Kuss D, Griffiths M. Social networking sites and addiction: Ten lessons learned. Int J Environ Res Public Health. 2017;14(3):311.

10. Reid Chassiakos Y, Radesky J, Christakis D, et al. Children and adolescents and digital media. APP. 2016;138(5):8.

11. Shabir G, Mahmood Y, Hameed Y, et al. The impact of social media on youth: A case study of Bahawalpur City. Asian J Soc Sci Human. 2014;3(4):132-51.

12. Anderson M, Jiang J. Teens, social media \& technology 2018. Pew Research Center [https://www.pewresearch.org/internet/2018/05/31/teenssocial-media-technology-2018/]

13. Warzecha K. Portale społecznościowe formą rozrywki i komunikacji współczesnej młodzieży - analiza statystyczna. Stud Ekon. 2017;318:84107.

\section{Corresponding author}

Dr Wojciech Brakowiecki

Chair and Department of Public Health, Medical University of Lublin,

1 Chodźki St., 20-093 Lublin

E-mail: witoldww20@gmail.com

tel: 692235417 